\title{
A POLÍTICA EDUCACIONAL CONSOLIDADA POR MEIO DO GRUPO ESCOLAR LAURO SODRÉ NO MUNICÍPIO DE MOJU-PA
}

\author{
Renato Pinheiro da Costa ${ }^{1}$ \\ Paulo Sérgio de Almeida Corrêa ${ }^{2}$
}

\section{RESUMO}

Com o início da República no Brasil setores importantes como a educação foram redimensionados, nesse sentido, no Estado do Pará foram criadas instituições de ensino com a intenção de alavancar o progresso social. Em Moju a força dessa ação do Estado é percebida através da história da educação que se apresenta ao longo desta pesquisa, por esse motivo este trabalho objetivou identificar a importância geopolítica da criação do Grupo Escolar Lauro Sodré para o município de Moju dentro de um projeto político do Estado para a implementação da política educacional republicana. Por isso partimos da problemática: Qual a importância geopolítica e educacional do Grupo Escolar Lauro Sodré instituído no Município de Moju? Desse modo, pautados no método histórico bibliográfico chegamos à conclusão que Moju se enquadra entre os municípios da região que teria a proposta de preparar a população para o desenvolvimento com a qualificação de mão-de-obra para atuarem nos setores sociais, e que a educação desenvolvida por meio do Grupo Escolar Lauro Sodré era a principal estratégia para atingir tais finalidades.

Palavras Chaves: Grupo Escolar; Estado; Educação.

\section{THE EDUCATIONAL POLICY IMPLEMENTED BY LAURO SODRÉ SCHOOL GROUP MUNICPIPIO MOJU-PA}

\begin{abstract}
With the beginning of the Republic in Brazil important sectors such as education have been resized accordingly, in Pará State educational institutions were created with the intention of leveraging social progress. In Moju the strength of this state action is perceived through the history of education that is presented throughout this research, therefore this study aimed to identify the geopolitical importance of the creation of the School Group Lauro Sodre for the city of Moju within a political project the State to implement the Republican education policy. So we start with the problem: What is the geopolitical and educational importance to the School Lauro Sodré established in the city of Moju? Thus, guided in the bibliographic historical method we concluded that Moju fits between the municipalities in the region that would have the proposal to prepare the population for development with the qualification of hand labor to work in the social sectors, and that education developed by the School Group Lauro Sodré was the main strategy to meet these goals.
\end{abstract}

Keywords: School Group; State; Education

\section{Considerações iniciais.}

Esta pesquisa que teve identificar a importância geopolítica da criação do Grupo Escolar Lauro Sodré para o município de Moju dentro de um projeto político do Estado para a implementação da política educacional republicana. Para tanto, foi realizada minuciosa pesquisa histórica que vai desde a fundação do Grupo Escolar Lauro Sodré localizado nessa unidade municipal, analisando sua inserção no contexto sócio/cultural e educativo do município. 
O problema de pesquisa que orientou a confecção desta parte do trabalho se expressou na seguinte formulação: Qual a importância geopolítica e educacional do Grupo Escolar Lauro Sodré instituído no Município de Moju?

Para esclarecer e refletir sobre tal indagação, consultei acervos consubstanciados em Decretos, Leis, Resoluções, Portarias que deram origem ao Grupo Escola de Moju, a gestão institucional, as políticas curriculares e aos dispositivos reguladores do trabalho docente, documento acessados na Biblioteca Pública do Pará, no site do Center for Research Libraries, Câmara de Vereadores de Moju e Arquivo da Escola Lauro Sodré.

Os Grupos Escolares simbolizam um projeto criado no início da forma de governo republicano como forma de desenvolver o ensino primário. $\mathrm{O}$ encaminhamento deste plano para os Estados ocorreu mediante a convergência dos governadores com o ideário políticoideológico expresso no republicanismo, que implantou nos municípios tais estabelecimentos de ensino, e através deles introduziram nas unidades federativas políticas educacionais, princípios ideológicos, aparelhamento predial, que possibilitou aos cidadãos maiores oportunidades de desenvolvimento.

As fontes de pesquisa constituintes deste capítulo, são parte do acervo disponível em sítios eletrônicos da internet, iconografias, documentos legislativos, arquivos escolares, buscados com base em estudos abordados em artigos, teses, livros e outras bibliografias que indicam tais acervos como ideais para a reconstituição histórica.

Este trabalho dissertativo situado na área da História da Educação segue a linha investigativa da história do desenvolvimento das Instituições Educacionais no Brasil, dando ênfase aos Grupos Escolares. Nesse sentido, acompanhando os atos e fatos respectivos desses estabelecimentos de ensino, os dados levantados em uma linha hierárquica: Deliberação da Administração Federal e Deliberação da Administração Estadual, é percebível que a seta da bussola, indicando para onde devemos rumar, poderia ser direcionada a qualquer município onde foi construída uma unidade de Grupo Escoar no Estado do Pará, que seria possível ser notado os sinais deixados pelas influências dessa instituição, pois pelos levantamentos realizados nos capítulos anteriores nota-se que no processo de implantação dessas unidades de ensino houve atividades políticas, trabalhistas, financeiras, comerciais, onde os Grupos Escolares marcaram a existência dos municípios nos quais foram implantados.

Moju ao ser escolhido como sede de uma das unidades de Grupo Escolar do Estado do Pará teve sua comunidade movimentada, pois, sua população não ficou isenta de se manifestar a respeito da edificação e dos resultados oriundos desse estabelecimento.

\section{Estudos, narrativas e abordagens da História do Município de Moju}

As histórias dos Municípios paraenses têm muitas fases, sendo que fazermos parte de um país com dimensões continentais e um processo de ocupação territorial que seguiu a lógica mercantilista ${ }^{3}$, ou seja, primeiro foram tomadas posses às regiões com mais fácil acesso e com produtos possíveis de comercialização, o que favoreceu certas províncias do país a se desenvolver economicamente mais do que outras. Dessa forma, no Estado do Pará ${ }^{4}$, a incursão do território durante o período colonial foi parca, não que tenha sido isento de sofrer tal invasão, mas somente os lugares acessíveis pela via marítima é que foram empossados, como resume Marin (2001).

A posse do território correspondente ao Município de Moju segue o ritmo da ocupação das terras que deu origem aos municípios que são de sua época, ou seja, segundo Nozoe (2006) a Coroa Portuguesa dava concessões de sesmaria para seus compatriotas a fim de marcar o território, por esse motivo é possível encontrar sesmeiros como Antônio 
Dorneles de Sousa ${ }^{5}$, Inácio Vaz Chaves $^{6}$ e Barão do Cairari ${ }^{7}$ como detentores de terras na região de Moju.

Seguindo esse itinerário é possível dizer que Moju embora não tivesse grande notoriedade por fazer parte de região pouco habitada, sua localização chamava atenção da Coroa Portuguesa por ter um rio de fácil navegação, terras produtivas, habitantes nativos para serem utilizados como mão-de-obra, e reunia todas as condições favoráveis para servir como ponto de referência da ocupação colonial.

Desde a fundação Moju sofreu com epidemias que hora dizimavam a população como descreve Leonardo M. F em 1849, citado em Moreira Neto (1998), sendo palco de conflitos como a cabanagem segundo Santos (2004) e crises políticas como citado em PARÁ (1870, p. 17) quando foi anulada pelo governo imperial a eleição de vereadores e juízes de paz realizada na freguesia de Moju em 7 de setembro de 1868, pois esse processo eleitoral tinha influência direta na Câmara de Vereadores da Capital.

Os fatos ocorridos na região mojuense foram diversos e todos eles contribuíram para sua consolidação como Município o que, segundo Lima (2000, p.n13), ocorreu através da promulgação da Lei n $^{\circ} 628$ de 06 de outubro de 1870 que elevou a Vila de Moju a categoria de Município.

Assumindo a condição de Município, Moju alcança outros patamares no cenário Estadual e Federal, começando a ter sua própria organização jurídica com a instituição de uma prefeitura e edificação da Câmara de Vereadores para legislar em matérias como dotação orçamentária e políticas públicas, também passa a dispor de serviços como saneamento e educação com a instituição do ensino primário.

Pelo relato encontrado em Lima (op. cit. p. 18/19) e no site do Instituto Brasileiro de Geografia Espacial - IBGE, devido à organização política do Pará, em 1930 Moju por não alcançar o teto orçamentário estipulado pelo Estado, perde seu título de município e seu território é incorporado ao Município de Belém, em seguida é ligado ao Município de Igarapé-Mirí , sendo extinta também sua sub-prefeitura com a nomeção de um Inspetor Municipal. Em 1933, Moju e outras circunscrições administrativas de outras localidades do Estado, que se encontravam na mesma situação de rebaixamento e tiveram suas terras agregadas a outros territórios retomam o status de Município autônomo.

Moju está localizado na mesorregião nordeste paraense, fazendo limite com os Municípios de Acará, Baião, Mocajuba, Breu Branco, Tailândia, Igarapé-Mirí, Abaetetuba, Barcarena, distante cerca de $65 \mathrm{~km}$ da capital do Estado, compreendendo uma área de $9.093,850 \mathrm{~km}^{2}$, com população estimada para $2009 \mathrm{em} 68.600$ habitantes segundo dados do IBGE/2009, na atualidade sua economia gira em torno da agricultura familiar, agro indústria, serviços públicos e do comércio logístico.

\section{A institucionalização do ensino em Moju e o Grupo Escolar Lauro Sodré integrado ao sistema educacional}

A preocupação da Província em prover as unidades de sua circunscrição com obras e serviços na tentativa de assegurar o desenvolvimento econômico e social da região exigia que houvesse incremento em setores essenciais como saúde, transporte, segurança, assim como em campos que atendessem ao público. Dependendo do tipo e do nível, esses investimentos podem indicar projeções da administração do Governo para a região. No caso de Moju, como era uma das localidades mais antigas da Província do Grão-Pará, de fácil acesso, com terras prósperas, o Governador Provincial de José Tomaz Henrique designou para a localidade a criação da primeira cadeira de Ensino Primário no ano de 1843, determinada pelo Decreto $\mathrm{n}^{\circ} 111$, descrito em PARÁ (1843), o que pode ser um indicativo das expectativas futuras de Moju. 
Com o início da organização municipal entre final do século XIX e início do XX, Moju passou a se estruturar melhor com aparelhamento de vias de acesso às localidades que fazem parte de seu território, porto para embarque e desembarque de produtos, serviços públicos, tudo o que um Município necessita para funcionar em condições adequadas.

Sendo municipalidade Moju adquiriu ligação especial com o Estado, contando com investimentos oriundos da instância superior e podendo administrá-los de modo autônomo em vista da implantação de políticas administrativas, como é o caso do setor educacional. Esse seguimento público tem exclusivo direcionamento, pois com a implantação da forma de governo da República o sistema de ensino muda radicalmente desde sua concepção até a estrutura dos estabelecimentos educativos.

Nesse sentido Sampaio (2004, p. 20) ao afirmar que: "É necessário notar como a concepção da época atribuía à organização da escola em "grupo escolar" o resultado da melhoria do ensino, melhoria que não seria possivel com as escolas isoladas". Esclarece que a determinação do Governo era de suprimir o sistema de escolas isoladas e em seu lugar disseminar o projeto de Grupos Escolares a fim de melhorar a qualidade do ensino primário. Assim, como consta em PARÁ (1907, p. 27), foi implantado o Grupo Escolar de Moju pelo Decreto $\mathrm{n}^{\mathrm{o}} 1.477$ de 2 de janeiro de 1907 durante o Governo de Augusto Montenegro.

Vale apena ressaltar que em Mensagem ao Congresso Legislativo do Pará, no ano de 1906, o Governador já faz alusão a implantação desse mesmo Grupo Escolar.

[...] Desde vossa ultima reunião foram fundados mais 3 grupos, sendo um na capital e 2 no interior (Faro e Gurupá), dos quaes um está funccionando há poucos dias. A media da matricula no 7 grupos da capital é de 495 alumnos: a da matricula nos 20 grupos do interior é de 247 alumnos. Estes algarismos são muito animadores. Acha-se também fundado mais um grupo no Mojú, onde foi preparada uma excellente casa [...] (PARÁ: 1906, p, 35)

Elegendo Moju como lugar para sediar a unidade do Grupo Escolar, o governo republicano coloca o município nos horizontes do desenvolvimento, nivelando sua estrutura organizacional a dos outros municípios que também receberam no mesmo período os recursos desse subsídio.

A exemplo dos desbravadores que ao chegar em lugar desconhecido o demarcam fixando sua bandeira e se firmando como dominadores, a construção do Grupo Escolar serve como marco de consolidação do republicanismo na região, pois a política de ensino do Governo Republicano não era novidade educacional, uma vez que o município já tinha o ensino primário desde o tempo imperial, mas o Grupo Escolar dentro de um projeto expansionista demarca território e reproduz ideais.

Por falta de arquivos fotográficos não foi possível expor a imagem do prédio do Grupo Escolar de Moju, deste modo, valendo-me do recurso da descrição a partir da narrativa de ex-alunos, pude ter noção do espaço físico da instituição escolar. O que demonstra a estrutura descrita é que o imóvel corresponde ao modelo de Grupo Escolar do período, com várias salas destinadas aos trabalhos administrativos e as atividades educativas do ensino primário, estrutura não ofertada nas escolas isoladas, por funcionarem na sala das casas dos docentes.

Pela descrição dos ex-alunos, o Grupo Escolar de Moju estava em um lote de terra medindo cerca de $20 \mathrm{~m}$ de largura por $45 \mathrm{~m}$ de comprimento, correspondendo a uma área global de $900 \mathrm{~m}^{2}$, tendo um muro cercando toda a área. O prédio do Grupo ficava no final do terreno tendo uma calçada de acesso. $\mathrm{Na}$ entrada, a direita estava a sala da Secretaria e a esquerda havia um busto homenageando o ex-governador Lauro Sodré fixado na parede e em seguida estava a sala da Diretoria, em seguida ficavam duas salas de aulas com entrada pela lateral da sala da direção, após as salas de aulas havia a copa e ao lado (no fundo do prédio) dois banheiros, um para os meninos e outro para as meninas, ao redor das salas havia 
um pórtico espaçoso que interligava todas os espaços. Na lateral direita havia uma área destinada ao lazer, em que todos que ajudaram na reconstituição da imagem foram unânimes em lembrar o balanço que havia naquele lugar.

Embora seja um prédio de apenas um pavimento, essa estrutura de escola para a época pode ser considerado a inovação em construções arquitetônicas, pois a formatação e divisão das salas destinadas para o trabalho administrativo com relação à disposição das salas de aulas e o serviço de copa-cozinha, permitiam melhor controle do acesso e permanência dos alunos nas aulas.

O Grupo Escolar de Moju, podendo ser considerado um marco desbravador do republicanismo na região, necessariamente não precisava conter todos os requisitos dos prédios escolares de seu tipo, a saber, como esclarece Vidal(2006) e Rosário (op.cit.) o diferencial de um prédio de Grupo Escolar para escola isolada e reunida está na quantidade de salas de aula, sendo a escola isolada composta de uma sala, a reunida duas salas de aula e o Grupo Escolar com mais de duas salas de aula.

Se levarmos em consideração a lógica adota pela autora para a caracterização do tipo de prédio, podemos classificar o edifício de Moju como escola reunida por conter apenas duas salas de aulas, contudo tanto Vidal quanto Rosário, quando tratam desse assunto apenas se referem a salas de aulas e ao trabalho docente, não fazem indicações de outras partes do prédio, como área administrativa, secretaria, banheiros, copa, cozinha, almoxarifado, área de lazer, calçadas etc. E o prédio escolar de Moju além das salas de aula continha outras dependências e dispunha de serviços não se restringindo ao trabalho docente, mas continha serviços de secretaria, direção e serviços gerais.

Neste sentido, o prédio escolar de Moju pode ser considerado como Grupo Escolar por desenvolver um trabalho voltado para o ensino primário e conter serviços além do docente em sua organização.

Por ser um prédio com pouca estrutura se comparado àqueles inaugurados na capital do Pará, podemos analisar que se levamos em consideração a demanda de alunos e serviços dos Grupos Escolares da capital com relação ao interior eram enorme as necessidades da cidade de Belém por conter maior quantidade de alunos, pois nas matriculas do ano 1919, por exemplo, em 10 dessas instituições existentes em Belém foi de 3.750 alunos enquanto que em 14 delas espraiadas pelo interior foi 2.573 alunos, ou seja, pela concentração populacional os Grupos Escolares da capital carecia de maior investimento em infraestrutura educacional do que o interior.

Santos e Aguiar (op. cit.) corroboram com a análise da maior aplicação dos esforços do Governo Estadual nos prédios escolares da capital em detrimento dos fixados no interior, pelo fato de os reformadores do ensino visarem, por pressões de natureza quantitativa, o aumento do número de escolas, o que as autoras deduzem ser o motivo da perda na excelência predial.

Assim, podemos compreender que quanto mais distante da capital, diminuía o rigor nas exigências do Grupo, questão que vai desde a aplicação de sua arquitetura até a forma de organização do trabalho institucional, pois no caso de Moju, pela descrição o Grupo não tinha desenho arquitetônico definido, nem contava com espaços mais elaborados como corredores, pavimentos, escadarias e outras estruturas mais concernentes a outros prédios de sua envergadura existentes na capital.

Como podemos perceber o Grupo Escolar de Moju, muito mais que um meio de oportunizar o ensino para a população, continha informações preciosas da conjuntura social, econômica, cultural e política do momento, pois, em suas paredes estavam guardados os ideais, interesses, articulações e vontades de pessoas e classes políticas que determinavam 
por onde a sociedade caminharia, utilizando o sistema de ensino como recurso de tal finalidade.

\section{A história através das fontes: os arquivos documentais auxiliares da pesquisa}

O desejo de difundir os ideais de igualdade, ordem e progresso comungados pelos republicanos precisava de meios para ser realizado, deste modo, o governo encontrou nas instituições de ensino o ambiente adequado para tal desiderato. $\mathrm{O}$ processo de divulgação dos ideais republicanos através do ensino chegou até Moju em meio às mudanças operadas no sistema escolar local, que antes ocorria em escolas primárias isoladas, e a partir de 1907 com a implantação do Grupo Escolar de Moju, dar-se-ia por meio do trabalho docente e do currículo oficial concentrado em um mesmo prédio arquitetônico.

Como normativa para as atividades docentes foi estabelecida em 1910 a reformulação do ensino primário, que determinava o método indutivo como modelo de ensino a ser empregado pelo professor em sua prática, haja vista, o sistema de ensino estadual orientar para a realização de atividades práticas em sala de aula em detrimento do uso do livro didático, de acordo como o descrito em PARÁ (1910). Além das disciplinas Português, História, Geografia e Aritmética, são instituídas novas matérias de estudo para o ensino primário como: Geografia, Botânica, Física, Lições de Coisas e Educação Moral e Cívica.

A Reforma Educacional do Estado do Pará teve repercussão aparentemente positiva, pois, além da organização do ensino ela também tratou do tema do trabalho docente, regulamentando que o provimento efetivo no magistério para o ensino primário fosse por meio de concurso assegurando promoção e vantagens como: Vitaliciedade e Classificação de Professores em $1^{\mathrm{a}} ; 2^{\mathrm{a}} ; 3^{\mathrm{a}}$ e $4^{\mathrm{a}}$ classes, segundo o parecer do Conselho Superior de Instrução Pública do Estado, relatado em PARÁ (1916, p. 27).

Tais regulamentações da reforma educacional instituída pelo Decreto $\mathrm{n}^{\circ} 1.689$ de 28 de abril de 1910, se tornam aparentes devido o fato que na falta do professor qualificado para assumir a cadeira em um Grupo Escolar, o Estado destinaria um profissional da capital para o interior. Mas, na verdade, muitas unidades foram prejudicadas devido ao não cumprimento dessa determinação, causado também pelo agravamento da crise financeira do Estado, descrito em PARÁ (1908, p. 62), o que levou o Grupo Escolar de Moju a ter o funcionamento suspenso no ano de 1909, mesmo apresentando a matricula de 146 alunos com frequiência confirmada de 134 no segundo trimestre de 1908, fato mascarado pelo governo que em pronunciamento oficial culpava pelo fracasso a falta de matrícula de estudantes na referida unidade de ensino.

Embora o Grupo Escolar de Moju tenha sofrido a suspensão de suas atividades durante cerca de 10 anos, isso não significa que o Município esteve a parte no serviço público educacional, pois além da estrutura do Grupo Escolar existia nesse período o sistema de escolas isoladas que necessitavam apenas de professores leigos e uma precária infraestrutura para funcionar, e que continuavam funcionando em localidades como Jambuaçu e Distrito de Cariry ${ }^{8}$, como descrito em PARÁ (1968) exigência com a qualificação do professor para o ensino primário se tornou um empecilho ao desenvolvimento do ensino nos Grupos Escolares, haja vista a Escola Normal de formação de Magistério estar situada em Belém, e geralmente, somente os moradores da capital tinham mais acesso a ela, os estudantes vindos do interior do Estado para continuar os estudos teriam que residir na casa de parentes onde sempre eram colocados para trabalhos domésticos o que lhe tomava todo o tempo, não restando espaço para a formação. Outra dificuldade estaria no destacamento dos profissionais formados para o interior, pois o salário oferecido pelo sistema público de ensino era baixo o que desestimulava a permanência de professores nas unidades de ensino 
fora da capital, fato registrado em PARÁ (1955, p 53) o que fazia decair o nível do ensino no interior.

\begin{abstract}
Por outro lado, é inadiável que se procure melhorar o nível do Corpo Docente das escolas do interior. Este, é um problema complexo. Enquanto o nível de vencimentos permanecer baixo, emquanto o interior do Estado não oferecer, como geralmente é o caso, condições mínimas de confôrto, então, será difícil obter que as normalistas pelo Instituo de Educação se disponham a seguir para o interior a ensinar as novas gerações. [...]
\end{abstract}

Em muitos casos as professoras destinadas à educação nas unidades do ensino primário fora da capital se valiam da distância para se beneficiar e faltar ao trabalho, pois longe da sede ninguém poderia vistoriar sua ausência ou forma de trabalho, fato constatado a partir do levantamento realizado pelo Departamento de Pessoal, o que confirma a diminuição do rigor no controle e manutenção com os Grupos Escolares do interior.

Por esse motivo o Governo criou o cargo em 1956 de Inspetor Geral do Ensino, sendo destinado à região que compreende os Municípios de Abaetetuba, Igarapé-Mirí, Moju, Cametá, Baião e Mocajuba o Inspetor Elias Miguel Alves.

A regularização e a fiscalização trabalhista do professor do ensino primário ante as determinações legais e idealistas do governo republicano valorizavam o profissional da educação e ao mesmo tempo melhorar a qualidade do ensino, pois as determinações governamentais exigiam do professor mais aplicação e melhor qualificação, desta forma Azevedo (2008, p. 1) afirma que:

Ao ser fruto da busca por mudanças no sistema de ensino primário e público nos estados brasileiros, os grupos escolares necessitaram de um novo profissional, com domínio dos novos métodos de ensino e adaptado a toda uma reorganização da escola que o Estado queria implementar, baseada, entre outras coisas, pela determinação da modalidade de ensino graduado [...]

O sucesso do projeto Grupo Escolar se deu pela visão empreendedora de educação que os governos tiveram para os Estados e Municípios, atuando simultaneamente nas melhorias da superestrutura e da infra-estrutura, adequando seu padrão aos exigidos pelo sistema de ensino nacional e a necessidade de atender a demanda de matrículas que aumentava a cada ano, como destaca Rosário (2006).

Estando entre os contemplados no Convênio Aliança para o Progresso, que visava a ampliação e construção de prédios escolares, o prédio do Grupo Escolar de Moju devido não ter condições de comportar o número de alunos matriculados que no ano de 1968 computou um total de 455, constatado em PARÁ (1968, p. 86.). Deste modo, no mesmo ano Moju foi contemplado com a construção de um novo prédio para sediar o Grupo Escolar Lauro Sodré com 5 salas de aulas, como consta em PARÁ (1969).

Segundo levantamento histórico, realizado no ano de 2008 pela direção da Escola para a comemoração do quadragésimo aniversário da instituição, narra que:

[...] inaugurada somente no dia 20 de fevereiro de 1968, já no atual endereço, Praça dos Estudantes n ${ }^{\circ} 50$, Bairro Centro.

Naquele ano, o Prefeito e o então Governador Coronel Alacide da Silva Nunes decidiram homenagear aquele que foi o primeiro governador constitucional do Pará em 1981, pertencente à Primeira República e que em seu segundo governo reorganizou o ensino público do Estado, um paraense de destaque Chamado Lauro Sodré, dando seu nome a Escola. (Levantamento da História da Escola Lauro Sodré. 2008, p. 1) ${ }^{9}$ 
Com a mudança, o prédio do antigo grupo Escolar foi demolido e em seu lugar construiu-se um novo edifício destinado ao funcionamento da Maternidade/Posto Médico e também ao FORUM da Comarca de Moju. Com a mudança da Instituição Jurídica Grupo Escolar Lauro Sodré para a nova edificação, o prédio antigo que abrigava o estabelecimento de ensino, para muitos pragmáticos, perdeu seu sentido e valor cultural, podendo ser utilizado para vários fins, ou até ser demolido.

O prédio antigo do Grupo Escolar, embora fosse um objeto inanimado, em suas paredes estavam guardadas as histórias e as memórias da população mojuense. A arquitetura, símbolo de um período áureo da história do Estado do Pará e de Moju, edificada nas vigas antigas poderiam contar muito do passado da institucionalização do ensino do Município. A estrutura física do edifício escolar serviria de comprovação dos dados educacionais, sociais, políticos, artístico, bem como dos movimentos ocorridos no século XX, pois para Le Goff (1996) os edifícios, os objetos, as lápides são constituídos documentos, por isso são essenciais para a pesquisa.

A preservação do espaço físico e de objetos do antigo Grupo Escolar seria de muita importância a constituição de acervo patrimonial histórico/cultural de Moju. Contudo, a realidade denuncia a omissão e o descaso das instituições, administrações, grupos, organizações, de órgãos e pessoas que não cuidaram desse tesouro precioso da memória dessa sociedade.

\section{A pesquisa através das fontes arquivadas}

Para fazer a reconstituição da institucionalização do ensino no Município de Moju a partir da edificação do Grupo Escolar Lauro Sodré, muitas instituições foram acessadas através do meio virtual da internet e visitadas presencialmente, principalmente no local onde se deu a pesquisa, a fim de ter contato com seus arquivos que para Medeiros (2003, p. 1) são:

\footnotetext{
"[...] conjuntos de documentos produzidos ou recebidos por órgãos públicos, instituições de caráter público e entidades privadas, em decorrência do exercício de atividades específicas, bem como pessoa física, qualquer que seja o suporte da informação ou a natureza dos documentos."
}

Através dos meios virtuais muitos documentos oficiais, artigos que abordam e remetem ao assunto pesquisado e iconografias foram encontrados. Com relação às instituições visitadas como bibliotecas públicas na capital, a pesquisa foi bem promissora por estes espaços conterem material bastante variado e em bom estado de conservação. Contudo, no que se refere ao lugar onde o objeto de pesquisa está localizado, a cidade de Moju, poucas informações registradas foram encontradas.

Sendo este um dos municípios mais antigos do Estado, sua estrutura administrativa era restrita ao prédio da Prefeitura Municipal ${ }^{10}$, por esse motivo todos os documentos tanto do Poder Executivo quanto do Legislativo, estavam concentrados em um único imóvel. Com a criação das secretarias, departamentos e a construção da Casa Parlamentar do Município muitos dos registros, decretos, ofícios, leis, recibos, relatórios, atas etc., foram danificados e perdidos no translado dos órgãos públicos de um setor para outro. Além deste fator, muitos volumes de pastas, cadernos, impressos e papeis avulsos antigos foram entendidos como lixo, sem valor, por isso destinados à incineração ou deixados ao relento sofrendo a ação do tempo.

Buscando referenciais nos órgãos do Município como Secretaria Municipal de Educação, Secretaria Municipal de Administração, Cartório do Único Ofício da Comarca de Moju, Câmara Municipal de Vereadora e famílias tradicionais da cidade, as respostas 
obtidas, em geral, remetiam ao descaso com o acervo e patrimônio público indicando a inexistência de dados mais antigos a respeito do tema pesquisado.

Em casos particulares como o da Câmara de Vereadores, embora os registros de ofícios, decretos, declarações etc., desde quando a Câmara foi instituída em 1870 com a criação do Município, não existam mais, o arquivo da Casa Legislativa permanece funcional, e a pesquisa de Carachanha (2009) indica que, além dos decretos e leis, os arquivos das Câmaras Municipais guardam também as atas de reuniões de vereadores contendo informações precisas por relatarem as falas dos parlamentares nas reuniões oficiais.

A partir dos levantamentos realizados na Casa Legislativa de Moju foi constatado que havia o registro das reuniões dos vereadores através das atas, contudo os registros existentes são somente a partir dos anos 1975, anterior a este período não havia nenhum documento disponível.

A partir dos registros em atas, o que se pode constatar é que as reuniões parlamentares abordam diversos assuntos referentes à vida política, social e cultural do Município, mas em muitos casos tratando especificamente do aforamento de terras e questões relacionadas à urbanização a partir da abertura de estradas e saneamento da cidade. A matéria educacional bem pouco aparece durante as cessões, a não ser em MOJU (1975, p. 43) quando é votado o orçamento para o ano de 1977 em que parte da dotação econômica é destinada ao setor, também durante a eleição dos membros das comissões parlamentares no mesmo ano, em que novamente o item educação aparece junto da Comissão de Saúde e Assistência Social.

A princípio o parecer dos vereadores é que dentre as questões de ordem da discussão legislativa a temática educacional não tinha tamanha importância. Contudo, embora Moju seja de longa data histórica, é somente durante a década de 1970 que o Município entrou na rota do novo ciclo de desenvolvimento econômico e social, quando começou a ser conectado por terra com a capital e outras regiões do Estado, favorecido pela abertura da Pa $150^{11}$ que atraiu vários projetos e investimentos para a região. Neste sentido, as atenções estavam voltadas mais para o incremento econômico e a questão agrária do que para às questões de ordem sociais como a educação.

Estando as atenções políticas do período direcionadas ao desenvolvimento econômico, outro fator que acomodava o poder municipal de intervir na educação primária era o fato de ela ser de responsabilidade do Estado, muito embora o município tivesse escolas de educação infantil como casulos ${ }^{12}$, mantidas com recursos próprios na cidade e na zona rural. No entanto, entendendo que as carências do setor eram enormes, em MOJU (1977, p. $128 \mathrm{v}$.) tem-se o seguinte relato:

O Senhor Presidente submeteu em primeira discussão e facultou a palavra [...] o Vereador Almir Pojo de Oliveira, que, (solicitou ao Sr. Oton Gomes de Lima) digo, que esclareceu que a exposição de motivos envida juntamente com o Projeto de Lei a vê compelida adquirir um transporte para os professores residentes na vizinha cidade de Abaetetuba, os quais vêm lecionando as $7^{\mathrm{a}}$ e $8^{\mathrm{a}}$ séries do $1^{\mathrm{o}} \mathrm{grau}$ a qual se justifica plenamente a solicitação que faz o poder executivo [...]

Ainda na década de 1970 o ensino primário sofria com as crises do sistema público de ensino, pois na sede do município não havia professores suficientes com formação adequada para atuarem nas disciplinas exigidas pelo currículo da época. Neste sentido, era imperioso que profissionais de outras cidades, como Abaetetuba, se deslocassem para Moju a fim de a Escola Estadual Lauro Sodré funcionar adequadamente atendendo as exigências legais do cumprimento do currículo escolar.

O fato de profissionais do magistério de outro município atuando em Moju pode ser indicativo de muitos fatores, como por exemplo, o de que o ensino primário local mesmo sendo quase centenário ainda não tinha alcançado a suficiência adequada ao ponto de formar 
quadros que pudessem assumir o ensino do município por completo. Mesmo porque ainda nesse período o ensino técnico secundário era ofertado em municípios como Abaetetuba e Belém, o que necessitaria que o aluno ao terminar o ensino primário devesse se deslocar para outro lugar caso aspirasse continuar os estudos e, quem sabe, retornar ao lugar de origem para atuar como professor.

Pelo pouco registro das reuniões dos parlamentares mojuenses, há o prejuízo na busca de informações a respeito da influência do Grupo Escolar Lauro Sodré no sistema de ensino local, pois a Câmara pode ter tratado de assuntos inerentes a essa questão nas sessões em períodos anteriores a 1970, neste sentido fica a incógnita dessa questão. Contudo, mesmo em poucas linhas, pode-se observar que o ensino primário da instituição Lauro Sodré se configurou uma questão pertinente para os legisladores, extrapolando os muros da escola chegando à casa parlamentar que mesmo em poucas palavras se movimentou a fim de contribuir com seu desenvolvimento e progresso.

Outra fonte de dados a respeito da implantação do sistema educacional de Moju seria a própria instituição objeto de pesquisa, atualmente Escola Municipal de Ensino Fundamental Lauro Sodré. Por ser originariamente o Grupo Escolar de Moju criado em 1907, embora em 1968 tenha mudado de residência, seu acervo documental deveria permanecer preservado, mas pelos mesmos motivos de não conservação de material documental ocorrido em outras repartições públicas do Município, na escola só foi possível encontra registros de matrículas dos alunos, livros de ponto dos funcionários, ficha de lotação, históricos escolares etc., dos anos 1969 em seguida. No mais, foi possível acessar as atas das reuniões escolares com registro a partir do ano 1977.

O arquivo da Escola Municipal Lauro Sodré, pelas atividades da instituição que vive em torno dos trabalhos letivos desenvolvidos durante o período escolar, é organizado de modo a ser funcional, ou seja, está dividido em duas partes, sendo: um ativo localizado na secretaria da escola, que por conter os dados dos alunos que ainda têm vínculo com a escola. Neste sentido o arquivo está em recorrente consulta, por isso precisa estar em curto alcance dos funcionários da secretaria. $\mathrm{O}$ segundo arquivo contêm os dados escolares tanto da instituição, quanto de ex-funcionários, funcionários e ex-alunos, que não estão em uso constante $^{13}$, por isso são guardados em uma sala a parte, sendo acessados quando requisitados. Neste sentido Gonçalves (2006) enfatiza que é hora de transformar este material em arquivo histórico, organizados, catalogados e integrados ao arquivo corrente dentro de uma política da instituição para a conservação e descarte de materiais.

A instituição de ensino acompanha a organização que o sistema de ensino em nível nacional e estadual adota. É importante ressaltar que o estabelecimento de ensino Lauro Sodré sofreu modificações quanto a sua nomenclatura. A instituição iniciou em 1907 como Grupo Escolar de Moju, em meados de 1968 como requisitado pelo governo, a fim de divulgar os ideais da República através de seus heróis, a instituição passou a ser nomeada de Grupo Escolar General Lauro Sodré. Em 1972 com a nova configuração da Lei de Diretrizes e Bases da Educação LEI N 5.692, DE 11 DE AGOSTO DE 1971, por força de decreto estadual determinou que o estabelecimento mudasse de Grupo Escolar e passasse a ser Escola Estadual de $1^{\circ}$ grau Lauro Sodré, mudança constatada nos documentos da época.

Às vezes as mudanças geram conflitos e, por conseguinte também acontece equívocos quanto a sua aplicação, nesse sentido, a LEI No. 5.692, DE 11 DE AGOSTO DE 1971 que altera a estrutura do ensino no país parece ter levado algum tempo para ser assimilada por completo, conforme as determinações oficiais (BRASIL: 1971):

Art. $1^{\circ} \mathrm{O}$ ensino de $1^{\circ} \mathrm{e} 2^{\circ}$ graus tem por objetivo geral proporcionar ao educando a formação necessária ao desenvolvimento de suas potencialidades como elemento de auto-realização, qualificação para o trabalho e preparo para o exercício consciente da cidadania. 
$1^{\circ}$ Para efeito do que dispõe os artigos 176 e 178 da Constituição, entende-se por ensino primário a educação correspondente ao ensino de primeiro grau e por ensino médio, o de segundo grau.

Parecem não ter sido de imediato adotadas as reformas educacionais em Moju, pois mesmo a Lei determinando a mudança no nome da Escola e na forma de graduar o ensino, os documentos de certificação de nível de ensino ainda continuavam a ser expedidos na forma antiga. Talvez para não prejudicar os educandos concluintes, em vista de não perderem as vantagens que um concluinte de ensino primário teria, ou dependendo do encaminhamento da Secretaria de Educação e Cultura, os alunos que já estavam no modelo educacional antigo não necessitariam ingressar no novo modelo. Portanto, todas as turmas do ensino primário teriam que concluir o ciclo que já haviam iniciado.

Pelo exposto, o cumprimento da legislação do ensino passava pela compreensão que o funcionário, que poderia ser o professor, o diretor, ou secretária, ou quem sabe pela mediação de pessoas externas como políticos tinham da realidade, pois em todos os efeitos um estudante que iniciava no ensino primário programado entre 4 a 6 anos, se matriculado no primeiro grau do novo sistema de ensino programado para 8 anos, teria que estudar mais 2 a 4 anos para concluir o ensino regular e passar ao grau seguinte. Isso não era bom nem para o Estado, que teria de arcar com as despesas do ensino, e nem para o estudante, que passaria mais tempo na escola.

\section{A sistematização do ensino mediante as legislações educacionais e suas implicações para o ensino em Moju}

Com a nova configuração na legislação do ensino, as mudanças nas unidades educacionais eram eminentes, pois desde a Decretação da Lei de Diretrizes e Bases da Educação $\mathrm{N}^{\mathrm{o}} 4.024 / 61$, o sistema educacional foi atingido por alterações em sua estrutura que afetaram diretamente o currículo e o trabalho docente (BRASIL: 1961).

\section{CAPÍTULO II \\ DO ENSINO PRIMÁRIO}

Art. 25. O ensino primário tem por fim o desenvolvimento do raciocínio e das atividades de expressão da criança, e a sua integração no meio físico e social. Art. 26. O ensino primário será ministrado, no mínimo, em quatro séries anuais. Parágrafo único. Os sistemas de ensino poderão estender a sua duração até seis anos, ampliando, nos dois últimos, os conhecimentos do aluno e iniciando-o em técnicas de artes aplicadas, adequadas ao sexo e à idade.

Art. 27. O ensino primário é obrigatório a partir dos sete anos e só será ministrado na língua nacional. Para os que o iniciarem depois dessa idade poderão ser formadas classes especiais ou cursos supletivos correspondentes ao seu nível de desenvolvimento.

No que se refere à formação do professor primário, para atuar no ensino do Grupo Escolar a Lei 4024/61, determina:

\section{CAPÍTULO IV}

Da Formação do Magistério para o Ensino Primário e Médio

Art. 52. O ensino normal tem por fim a formação de professores, orientadores, supervisores e administradores escolares destinados ao ensino primário, e o desenvolvimento dos conhecimentos técnicos relativos à educação da infância.

Art. 53. A formação de docentes para o ensino primário far-se-á: 
a) em escola normal de grau ginasial no mínimo de quatro séries anuais onde além das disciplinas obrigatórias do curso secundário ginasial será ministrada preparação pedagógica;

b) em escola normal de grau colegial, de três séries anuais, no mínimo, em prosseguimento ao vetado grau ginasial.

Art. 54. As escolas normais, de grau ginasial expedirão o diploma de regente de ensino primário, e, as de grau colegial, o de professor primário.

Art. 56. Os sistemas de ensino estabelecerão os limites dentro dos quais os regentes poderão exercer o magistério primário.

Art. 57. A formação de professores, orientadores e supervisores para as escolas rurais primárias poderá ser feita em estabelecimentos que lhes prescrevem a integração no meio.

As medidas adotadas pela Lei 4.024/61, eram consonantes ao milagre educacional do período em que o país vivia. Em que o sonho do progresso exigia que grande número da população em idade escolar estivesse na escola, qualificando-se para o mercado. Logo, o ensino passou por readaptações, exigindo que o quadro técnico tivesse formação suficiente para lecionar.

Em muitos casos, além da exigência da formação certificada, os docentes de Moju mesmo lotados na Secretaria Estadual de Educação, sofriam com a influência do poder político local. Que segundo o depoimento de professores aposentados, muitas vezes interferia solicitando a exoneração de funcionários junto ao Estado, por não comungarem com seus ideais partidários, ou serem de famílias opositoras, representando ameaça ao poder do administrador local. Quando não conseguiam, transferiam o docente para a zona rural em localidades como Pirateua, ou Jambuaçu na Escola Paisandu, ou alguma localidade do alto rio Moju, o que dificultava a vida do profissional, pois eram localidades de difícil acesso

A perseguição de políticos aos docentes era desmedida, posto quererem mostrar sua autoridade, por isso utilizavam o poder a fim de influenciar os responsáveis pelo sistema de ensino do Estado e colocar o professor em situação constrangedora. Nesse sentido cito o caso de quando foi trazido para Moju o inspetor educacional da região para forçar a Professora Ernestina Pereira Maia ${ }^{14}$ a se deslocar da cidade para a zona rural, investida que não obteve sucesso devido à docente ser empossada por portaria assinada pelo Governador Alacid da Silva Nunes.

Pelo testemunho de Maria de Fátima Nery, filha da professora Ernestina, por conta das perseguições, sua mãe com toda a família vivia em peregrinação hora no alto, hora no baixo rio, com o minguado salário, mas com dignidade e coragem enfrentava as situações e os políticos que a perseguiam, utilizando-se dos recursos de articulação, pois, por ser de família tradicional do lugar tinha conhecimento entre os políticos da região, chegando a dizer: "Tão me vendo coberta de lama pensando que sou ovelha!'. Frase que exprimia a batalha travada entre docente e poder político, onde o prejuízo maior acumulava para o setor educacional.

A legislação seguinte Lei $\mathrm{N}^{\circ}$. 5.692/71, em BRASIL (op.cit.) que trazia a mudança de ensino primário e ginasial, para ensino de $1^{\circ}$ e $2^{\circ}$ graus determinava que:

Art. $2^{\circ} \mathrm{O}$ ensino de $1^{\circ}$ e $2^{\circ}$ graus será ministrado em estabelecimentos criados ou reorganizados sob critérios que assegurem a plena utilização dos seus recursos materiais e humanos, sem duplicação de meios para fins idênticos ou equivalentes. Parágrafo único. A organização administrativa, didática e disciplinar de cada estabelecimento do ensino será regulada no respectivo regimento, a ser aprovado pelo órgão próprio do sistema, com observância de normas fixadas pelo respectivo Conselho de Educação.

Art. $4^{\circ}$ Os currículos do ensino de $1^{\circ}$ e $2^{\circ}$ graus terão um núcleo comum, obrigatório em âmbito nacional, e uma parte diversificada para atender, conforme 
as necessidades e possibilidades concretas, às peculiaridades locais, aos planos dos estabelecimentos e às diferenças individuais dos alunos.

Além de reorganizar a forma do ensino do país, a lei da educação de 1971 (BRASIL: op.cit.) com relação ao trabalho docente, estipulou que:

\section{CAPÍTULO V}

Dos Professôres e Especialistas

Art. 29. A formação de professôres e especialistas para o ensino de $1^{\circ}$ e $2^{\circ}$ graus será feita em níveis que se elevem progressivamente, ajustando-se às diferenças culturais de cada região do País, e com orientação que atenda aos objetivos específicos de cada grau, às características das disciplinas, áreas de estudo ou atividades e às fases de desenvolvimento dos educandos.

Art. 30. Exigir-se-á como formação mínima para o exercício do magistério:

a) no ensino de $1^{\circ}$ grau, da $1^{\mathrm{a}}$ à $4^{\mathrm{a}}$ séries, habilitação específica de $2^{\circ}$ grau;

b) no ensino de $1^{\circ}$ grau, da $1^{\mathrm{a}}$ à $8^{\mathrm{a}}$ séries, habilitação específica de grau superior, ao nível de graduação, representada por licenciatura de $1^{\circ}$ grau obtida em curso de curta duração;

c) em todo o ensino de $1^{\circ}$ e $2^{\circ}$ graus, habilitação específica obtida em curso superior de graduação correspondente a licenciatura plena.

$\S 1^{\circ}$ Os professôres a que se refere a letra a poderão lecionar na $5^{\mathrm{a}}$ e $6^{\mathrm{a}}$ séries do ensino de $1^{\circ}$ grau se a sua habilitação houver sido obtida em quatro séries ou, quando em três mediante estudos adicionais correspondentes a um ano letivo que incluirão, quando fôr o caso, formação pedagógica.

Os incrementos na legislação educacional deixam evidente a ênfase no tecnicismo que o ensino começa a tomar apoiado na manutenção socioeconômica do governo militar. Portanto, a cada reorganização, aumenta-se a quantia de anos, a forma, o lugar, qual o perfil do público se pretende atingir, o modelo de ensino pretendido, o quadro profissional. Desde a legislação de 1961 são projetadas as bases formais do ensino conformado com as exigências do modelo econômico do país. Não havia interesse em se modificar todo o texto da Lei n. 4.024/61, mas sim alguns de seus dispositivos, a fim de que se pudesse garantir a continuidade da ordem socioeconômica. Assim, o currículo do ensino primário das décadas de 1960 e 1970 demonstram que não houve mudanças, mas sim conformidade e continuidade do projeto nacionalista voltado para o desenvolvimento progressista da nação.

A lei 5.692/71 em comparação com a Lei 4024/61, amplia o currículo escolar com mais disciplinas voltados para atividades lógicas, exatas e práticas, ou seja, até 1971 o currículo oficial era composto das disciplinas: Português, Matemática, Estudos Sociais e Ciências Naturais. A partir do ano 1971 as disciplinas passam a ser divididas por áreas como: COMUNICAÇÃO E EXPRESSÃO compreendendo: Língua Portuguesa, Educação Artística, Frances (não obrigatório) e Inglês (não obrigatório); CIÊNCIAS compreendendo: Ciências, Matemática, Integração Social; ESTUDOS SOCIAIS compreendendo: História, Geografia, Educação Moral e Cívica e ORGANIZAÇÃO SOCIAL E POLÍTICA DO BRASIL - O.S.P.B; ARTES PLÁSTICAS compreendendo as disciplinas: Artes Industriais, Técnica Agrícola, Técnica Comerciais e Educação Para o Lar.

Dependendo do nível de ensino, algumas destas disciplinas não eram de freqüência obrigatória, mas no fundo exprimiam a ideário governamental que para Bittar e Junior (2006) atendem a interesses de dominação que as classes subalternas são submetidas aos padrões de igualdade exprimida pela escola, onde a iniquidade social está perpetuada nos modos de organizar o sistema educacional e o ensino.

Embora os padrões educacionais fossem de uma base comum para toda a nação, as condições de ensino não eram as mesmas em todas as regiões, pois a desigualdade na economia, no acesso, na qualificação profissional, de um município para o outro da região 
Guajarina, eram enormes, mesmo assim, o corpo técnico e docente da Escola Lauro Sodré dedicou-se para ofertar aos alunos uma educação segundo as condições materiais disponíveis à época.

Os artefatos documentais do acervo da Escola Municipal Lauro Sodré expõem em parte a realidade dos trabalhos que os profissionais da educação exerceram a partir da segunda metade do século XX, sendo que o relatado em ata demonstra a preocupação da direção da Escola com o desenvolvimento do trabalho educacional como um todo, como é narrado:

[...] Após a apresentação foi realizada a leitura das atribuições inerentes à função do supervisor dentro da escola. Conhecer a comunidade em que as unidades escolares estão inseridas. Elaborar e submeter a aprovação da Equipe Regional da de Ensino o Planejamento. Organizar e manter atualizado um arquivo em que contenha dados estatísticos das escolas sob sua responsabilidade. Elaborar gráficos de rendimento escolar e, juntamente com os Orientadores Educacionais, analizá$\underline{\text { los. }}$. Colaborar nas atividades afins do serviço de Orientação Educacional a Conhecer a estrutura administrativa das escolas sob sua responsabilidade. Colaborar com a direção da escola na elaboração de normas para horário escolar, matrícula, conferição de turmas, uso de técnicas e recursos didáticos, planejamento de atividades, experiências didáticas, integração e articulação horizontal e vertical de _ Orientar na elaboração e execução do currículo, adequando-o às necessidades do educando, da escolar, da comunidade e dos avanços técnicos na área educacional, econômica e sócio-cultural _ Proporcionar condições favoráveis de trabalho na escola _ Assistir e orientar os professores na elaboração de seu planejamento _ Promover reuniões periódicas com corpo Docente, Coordenadores de série ou áreas de ensino sistema de avaliação do rendimento escolar, recuperação de estudos Conselho de Classe, Associação de Pais e Professores Diretorizes da Unidade Escolar _ Facilitar a entrosagem e intercomplementaridade _ Acompanhar, controlar e avaliar a execução do planejamento do professor e da escola em cada período letivo, através de encontros, relatórios e outras atividades _ Atualizar os professores quanto a bibliografia especifica _ Dar sugestões na elaboração do Calendário Escolar _ Informar à Equipe Regional de Supervisão de Ensino sobre os resultados obtidos no desenvolvimento do currículo _ Planejar, orientar e coordenar os Conselhos de Classe. Promover atualização dos processos _ Analisar as informações _ Reformar o planejamento de maneira a atender as necessidades, em âmbito escolar e regional Encaminhar as informações colhidas na região para a equipe central [...] (Livro Ata das Reuniões Administrativas e Pedagógicas da Escola Lauro Sodré. 1977, p. 2)

Como se pode observar, as atribuições do Supervisor Educacional da Instituição eram muitas, tendo que exercer funções que atingiam outros estabelecimentos de ensino, isso se deve ao fato que por ser o primeiro Grupo Escolar do Município a instituição de ensino Lauro Sodré até o ano de $2001^{15}$, funcionou como Escola Sede, ou seja, para essa unidade de ensino eram remetidas todas as determinações e investimentos do Estado, e dela emanava para outras instituições educativas, tanto da zona urbana quanto rural.

Além da atuação técnica do Supervisor que visavam corroborar para o bom desempenho das atividades do corpo docente, discente e realização das atividades educacionais da instituição, o profissional precisava estar atento para levar às reuniões pedagógicas assuntos do dia-a-dia da escola, como quando chegavam à instituição novos professores que ainda não tinham a experiência do magistério e por isso, nas reuniões era proposto que houvesse troca de experiência entre os colegas profissionais para amenizar a precária situação do ensino.

A Escola Lauro Sodré vivia um intenso senso de conscientização e organização administrativa em vista da melhoria da qualidade do ensino. Pelas narrativas das atas foi 
possível perceber que a preocupação dos membros da instituição não era somente com os horários, as disciplinas, os planos de aulas, havia uma política organizacional que levava a instituição a debater as questões sociais como a relação aluno e família, integração da comunidade estudantil na sociedade, e o preparo e inserção dos profissionais nos problemas educacionais, de modo que durante o Planejamento Geral do ano letivo de 1979 foi estabelecido como objetivo da Escola:

A Escola Estadual de $1^{\circ}$ Grau Lauro Sodré, ciente da mentalidade dependente de que é vítima o povo em geral, se propõe proporcionar a todas as atividades em classe e estra-classe, oportunidade de participar - criar - agir por iniciativa própria e valorizar as possibilidades inerentes a cada um. (Livro Ata das Reuniões Administrativas e Pedagógicas da Escola Lauro Sodré. 1977, p. 8)

Através do ensino a expectativa era que houvesse a ascenção do indivíduo tornandose independente e consciente, por isso a escola se preparava através dos planejamentos e reuniões o que refletia o momento social em que Moju passava no final da década de 1970 e início dos anos 1980.

A Diretora da Escola na época, era a Religiosa Irmã Cecília Petrina de Carvalho tendo forte ligação com os movimentos sociais e sindicais que na época viviam intensa luta pelo direito à terra, em favor dos direitos dos trabalhadores rurais e contra as empresas que estavam se estabelecendo na região como: REASA, AGROMENDES, CRAI, DEMPASA e SOCOCO, segundo descrição de Sacramento (2009, p. 31), o que refletia o momento político e de luta social que o Município atravessava levando as instituições publicas governamentais e não governamentais a tomada de posição frente aos constantes embates e crimes que ocorriam. Assim, a comunidade escolar do Lauro Sodré optava em preparar-se para ter a posição mais coerente, dessa forma seu corpo técnico trabalhava no sentido de despertar a comunidade para os problemas sociais da época.

Por ser uma instituição pública ligada ao Estado Federativo, as atividades da Escola Lauro Sodré, enfatizavam célebres datas como: Dia das Crianças, Dia dos Pais, Dia das Mães. Também se empenhava em despertar nos alunos o sentimento de amor à Pátria, demonstrado nos desfiles que participava no dia 7 de setembro e Dia da Raça, momento que os alunos e professores aproveitavam para divulgar à sociedade as dificuldades que os afligiam através de exposição de temas como: Ecologia da Amazônia, Segurança Nacional, levantando questões polêmicas que provocavam a reflexão da população e chamavam a atenção das autoridades.

O padrão educacional em vigor no início de 1980 era determinado pela lei 5.692/71, que por ter sido constituída nas entranhas da ditadura militar cerceava, através dos parâmetros técnicos, as manifestações, mas a luta pela democratização no ensino era realizada através de associações de professores e movimentos estudantis, faziam forte resistência de oposição ao programa ditatorial em favor da melhoria da qualidade do ensino, com construção de mais escolas, liberdade de expressão, eleição para diretores de escolas, assim como a sociedade civil se organizava contra o comando dos militares através de mudanças na política brasileira, na educação os professores, corpo técnico, alunos e pais em âmbito regional (Abaetetuba, Barcarena, Igarapé-Miri e outros) também lutavam por mudanças no sistema de ensino, pois compreendiam que a estrutura educacional da época era construída de forma hierárquica, favorecendo determinados setores sociais, que os sindicalistas chegavam a comparar sua divisão a divisão das classes sociais representada pela pirâmide da divisão social.

A "Pirâmide da Educação" desenhada na década de 1980 com a figura do político no topo, em seguida assumindo posições os órgãos Ministério da Educação, - M.E.C, Secretaria 
Estadual de Educação - S.E.D.U.C., as Divisões de Ensino Regionais, mais a baixo o cargo comissionado de Diretor, em penúltimo ocupando os mesmo quadro da pirâmide os Professores e funcionários dos Auxiliares de Serviços Gerais (serventes e vigias) e por último sustentando a base da edificação hierárquica os alunos e pais de alunos. Essa imagem representava como o sistema de ensino era visualizado na região e como a educação adquiria a forma burocrática de organização, pois havia sempre o político no topo manipulando os órgãos técnicos, interferindo na vida e trabalho dos personagens da base.

Em vista da forma como os políticos agiam com relação ao ensino em Moju, perseguindo funcionários por causa das manifestações e de seus movimentos em favor de melhorias para a cidade e as escolas, os profissionais da educação se organizavam para através dos meios legais assumir os setores importantes da educação, questão exposta através da CARTA ABERTA AO POVO MOJUENSE colocada em circulação em meados da década de 1980, tempo impreciso devido o documento não ser datado, contendo o seguinte teor:

\section{CARTA ABERTA AO POVO DE MOJU}

Caros Mojuenses,

Nós, pais e professores de Moju, querermos colocar-lhes a par de uma situação injusta que vem sofrendo as nossas Diretoras, professoras e serventes, ao serem ameaçadas por certos políticos, de perderem o emprego.

Sabemos muito bem como era a Educação em Moju, anos antes da nossa inesquecível Irmã Cecília chegar. Foi ela que empreendeu todos os esforços e deu um grande impulso à Educação, conseguindo implantar aqui o Primeiro Grau.

Vendo que se aproxima o dia de ir embora, a preocupação de Irmã Cecília foi a de deixar pessoas que a substituíssem na dura missão de dirigir as Escolas.

Foi assim que movimentou os professores e conseguiu ajuda financeira da Comunidade para que as Professoras IDERCI e IOLANDA fossem para Castanhal, as quais deixando até mesmo a família e enfrentando inúmeros sacrifícios, dedicaram-se incansavelmente ao estudo.

Foi em agosto de 1982 que elas concluíram a Licenciatura Plena em Administração e com muita vontade e esperança assumiram a Direção das duas Escolas demonstrando bastante capacidade para isso.

Mas eis que surge o "Diretório do PMDB de Moju, encabeçado pelo Tenente Reis e apoiado pelo Coronel Alacid, que usando corruptamente de sua autoridade ameaça dispensar do emprego pessoas capacitadas colocando em jogo toda a Educação Mojuense.

Muitas coisas já foram feitas para evitar tal atitude que prejudica a Coletividade.

A Associação Mojuense de Professores (AMOP) deu alguns passos como:

* Entrou em contato com alguns Deputados do PMDB que se declararam contra esta atitude do Diretório.

* Redigiu ofícios e os entregou pessoalmente ao Coronel Alacid Silva Nunes, ao Dr. Jader Barbalho e à Professor Ruthe, secretária de Educação.

*Teve uma audiência como Dr. Jader Barbalho que também deu todo o seu apoio aos professores e concordou que esta atitude é bastante injusta e que se deveria conseguir o apoio da Comunidade.

* Contactou com a Secretária da Educação que prometeu jamais assinar qualquer Portaria de Demissão.

* Teve também um Encontro com o Coronel Alacid que se declarou do lado do Diretório.

Aproveitando de uma Reunião dos Pais convocada pela Direção da Escola para tratar do Ano Letivo, a AMOP se pronunciou para a levar ao conhecimento dos pais todo o problema que está acontecendo na Educação Mojuense, por parte de políticos.

Nessa Reunião, os pais não encontraram motivos justos para tais demissões e por isso apoiaram totalmente a permanência das duas Diretoras e demais funcionários e RESOLVERAM criar uma COMISSÃO que irá até as Autoridades levando um 


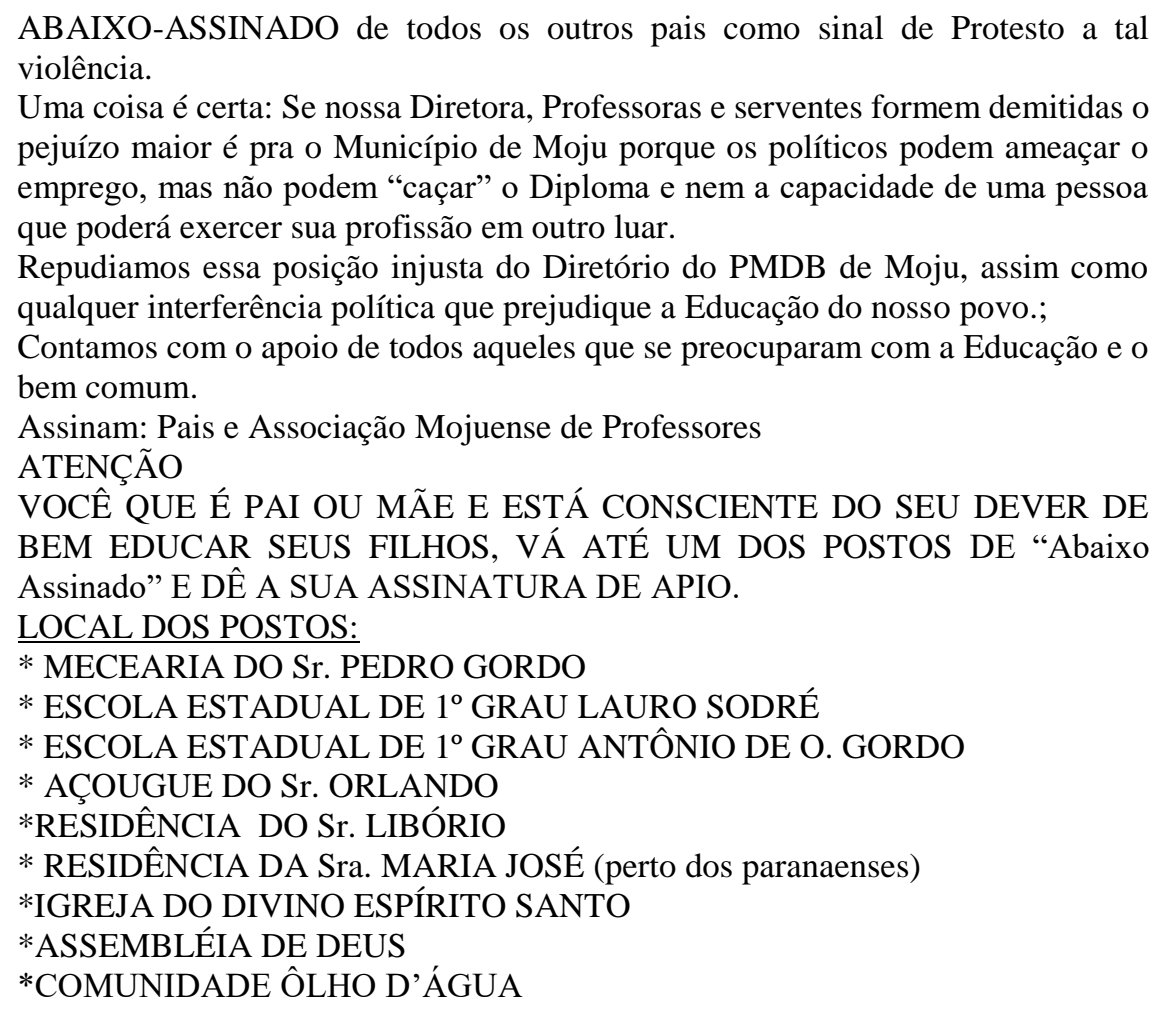

A carta dos professores expõe a manifestação e mobilização da categoria da educação e de toda a sociedade mojuense contra as articulações políticas. Nesse cenário, a Escola Lauro Sodré esteve presente, pois era o cargo dos funcionários da instituição, inclusive o de Diretor, que estavam entre os marcados com os políticos locais envolvidos em questões partidárias. Sendo a Escola Sede do Município, os prejuízos que afetassem essa instituição conseqüentemente atingiriam o ensino primário e todas as outras instituições escolares da cidade como a Escola Estadual de Primeiro Grau Antônio de Oliveira ${ }^{16}$ Gordo, citada entre os locais de coleta de assinaturas e as escolas da zona rural.

Os embates envolvendo as instituições de ensino e a questão política partidária em Moju gerou muitas crises no sistema público de ensino envolvendo em seu bojo diretores de escolas, professores, serventes, vigias, alunos, pais e organismos externos como sindicatos, igrejas e associações. Os resultados desse embate que por um lado foram prejudiciais, pois se perdia muito tempo e criavam muitas tensões entre as pessoas de uma pequena comunidade, por outro lado, foram fundamentais para o fortalecimento das instituições sociais, para o maior envolvimento e compromisso tanto dos membros da comunidade escolar quanto da classe política. Nessa direção Bittar e Junior (op. cit. p.1169) enfatizam que:

Os professores públicos estaduais de $1^{\circ}$ e $2^{\circ}$ graus se constituíram em um dos protagonistas sociais da transição democrática não apenas como uma categoria profissional em si, mas, sobretudo, por meio de uma intervenção programática própria no âmbito da formação societária brasileira no período correspondente às décadas de 1970 e 1980 . [...]

As manifestações ocorridas em Moju que fazem parte do contexto das mobilizações que se propagavam pela região Guajarina, pelo Estado do Pará e por todo o país, eram o marco da luta por mudanças no sistema de ensino, com maiores garantias paras os profissionais da educação, estabilidade de emprego, reajuste salarial, valorização do magistério, democratização, inovação metodológica. Eram apelos pela promulgação da nova Lei de Diretrizes e Bases da Educação Nacional, que suprisse as deficiências da Lei 5.692/71 
e assumisse novas configurações pedagógicas, pois o currículo, a estrutura educacional, a atividade docente, e outras composições do sistema de ensino de Moju já não correspondiam às exigências dos novos tempos.

A promulgação da nova Constituição Federal no ano de 1988, trouxe mais esperança para a categoria dos profissionais da educação e indicativos de melhorias para o sistema de ensino, pois, no inciso VI do artigo 30 desse texto legal, diz que: "compete aos Municípios: VI - manter, com a cooperação técnica e financeira da União e do Estado, programas de educação infantil e de ensino fundamental". Embora a questão educacional seja tratada de forma geral, o mencionado Artigo 30 abre prerrogativa para as inovações tanto no investimento quanto para mudanças significativas no ensino primário. Com a promulgação da nova LDB 9.394/96 as expectativas são concretizadas, pois, no Título V que trata da Organização da Educação Nacional (BRASIL: 2003, p. 30) a responsabilidade e envolvimento além da União e do Estado, os municípios, dos estabelecimentos de ensino, dos docentes nessa questão.

Com a nova Lei de Diretrizes e Bases da Educação 9.394/96, o sistema de ensino de Moju tornou-se mais forte, as determinações da regulamentação da educação supostamente representavam mais investimentos e melhor infra-estrutura para o setor, sendo que o município teve que aprender a gerenciar melhor os recursos destinados à educação, aparelhar melhor os estabelecimentos de ensino.

Nesse processo de reestruturação do ensino municipal de Moju para se adequar as exigências da nova legislação, e a Escola Lauro Sodré por ser estadual, também começava a dar sinais de sua adequação às novas estruturas, cria assim, no ano de 1996 o Conselho Escolar, com a representação os membros da comunidade escolar envolvendo técnicos, professores, servidores, alunos, pais, responsáveis e membros da comunidade onde a escola está localizada como consta na Ata do Conselho Escolar da Escola Lauro Sodré (1996), que entre as atribuições que lhe conferiu sempre esteve atenta ao controle e fiscalização dos recursos do Fundo Nacional de Desenvolvimento da Educação - FNDE, também se mostrou incansável para garantir o processo democrático da escola através da luta pela eleição do cargo de Diretor e Vice-Diretor.

Com a descentralização do ensino, o processo de municipalização da educação ganhou forças no Estado do Pará, que repassou aos municípios a responsabilidade com o ensino fundamental, tendência seguida pela linha de pensamento neoliberal visando desatrelar do Estado o compromisso com questões de ordem social. Portanto, os municípios ficaram incumbidos com prioridade do ensino fundamental via convênios e regime de cooperação técnica e financeira segundo constatação de Souza (2005).

A Escola Lauro Sodré aderiu ao processo de descentralização no ano de 2001, igualmente as outras escolas do Estado em que funcionava o ensino fundamental em Moju, o que por um lado tornou os estabelecimentos de ensino mais próximos do controle, fiscalização e da organização técnica do município, pois quando a instituição era estadual, os profissionais tinham mais autonomia em suas ações tanto pedagógicas quanto sindical.

Pelos dados pesquisados, que remontam ao início da institucionalização da educação de Moju entre final do século XIX, a administração do espaço e do próprio sistema de ensino municipal ficou por conta do governo estadual, que através das articulações políticas, nomeava docentes e sobretudo os administradores da unidade de ensino. A partir da mudança do prédio antigo do Grupo Escolar para o novo estabelecimento no ano de 1969 se tem a lista das sucessões ocorridas no cargo de administrador da instituição sendo: Maria Marlene Queiroz dos Reis (1969 a 1970); Maria do Carmo Melo (1970 a 1971) Maria Isabel Solano de Miranda (1971 a 1972); Maria das Graças França Borges (1972 a 1973); Ucimar Pina Pereira (1973); Carmem Barata (1973 a 1977); Irmã Cecília Petrine de Carvalho (1978 a 
1982); Iderci Lima de Santos (1982 a 1983); Julieta Santos Gordo (1983 a 1986); Iolanda Costa Amara (1987 a 1989); Idilena das Graças Siqueira (1990 a 1999); Raimundo Roberto Almeida Ribeiro (1999 a 2001); Maria Augusta Nery Cristo (2001 a 2004); Ivone Fernandes da Silva (2005 a 2010).

A relação supra descrita mostra a oscilação dos educadores na direção do Grupo Escolar Lauro Sodré. As razões para a constante movimentação no setor administrativo da instituição pode ter diversos motivos para acontecer, no entanto, um fator positivo nas mudanças ocorridas, é a abertura possibilidade para os educadores terem experiência no contexto educacional além da sala de aula, e que estes mutuamente contribuíssem com o estabelecimento educacional a partir do modo como concebiam o desenvolvimento do papel do diretor.

Logo no início da mudança de prédio a sucessão administrativa do Grupo Escolar era frequente, pois, sendo a direção do Grupo Escolar e escola sede do município um cargo de grande prestígio social, muitos políticos cobiçavam tê-lo sob sua gerência, por isso a razão de algumas administrações durarem apenas um ano e também alguns gestores serem alvos de perseguição política.

Atualmente a Escola de Ensino Fundamental Lauro Sodré conta com uma estrutura física composta de dois blocos com 10 salas de aulas, sendo o segundo de dois andares; uma sala de educação física; um terceiro bloco destinado a uma biblioteca; uma sala para a direção; um auditório utilizado como copa, uma cozinha; uma sala para os professores; uma secretaria; uma sala para arquivo; um estúdio de radio; área de recreação com quadra poliesportiva, compreendendo a uma área global de $1.100 \mathrm{~m}^{2}$.

Em termos de profissionais, na atualidade, a Escola dispõe de um quadro de funcionário composto de: Uma Diretora, duas Vices-Diretoras, dois Coordenadores Pedagógicos, quarenta e oito Professores, nove Agentes Administrativos, dez Serventes; e um mil trezentos e oitenta e três alunos matriculados em 30 turmas sendo 20 do ensino fundamental e 10 da modalidade Educação de Jovens e Adultos.

Atualmente, Moju possui 191 escolas sendo 15 na zona urbana e 176 na zona rural. Algumas escolas da zona rural estão ofertando o ensino médio através do Sistema Modular de Ensino - SOME, e duas escolas da zona urbana a Escola Estadual de Ensino Médio Professora Ernestina Pereira Maia e Escola Municipal de Ensino Fundamental e Médio Antônio de Oliveira Gordo ofertam o ensino médio regular. Todo esse aparato está vinculado diretamente à Secretaria Municipal de Educação - SEMED, que coordena e orienta o programa de trabalho das unidades de ensino.

\section{Considerações finais}

A atual estrutura sistêmica que configura o ensino de Moju tem sua base alicerçada no processo histórico de sua constituição, iniciada com a instituição da cadeira do ensino primário no século XIX e fundamentada com a criação do Grupo Escolar de Moju, que configura o estabelecimento fixo do ensino que ganha forma em paredes e vigas edificadas, e assume um importante lugar na vida social e cultural do município, pois os agentes que passaram pelo estabelecimento de ensino primário, ao longo da formação histórica de Moju foram gerando ações, relações, consciência, conflitos, estabeleceram embates, políticas, incômodos. A partir da institucionalização do ensino, com a criação do Grupo Escolar de Moju, outros setores como a economia, a política, a cultura, o povo, foram movimentados, tocados e transformados mediante os avanços conseguidos pelo viés da educação. 
A partir do estabelecimento do ensino em Moju com o Grupo Escolar, foi possível dizer que o município se enquadra entre os municípios que vislumbravam alcançar o desenvolvimento, pois sua população seria preparada através da escola para assumir funções nos espaços do setor da indústria, comércio, produção em grande escala, ou seja, estaria preparado para o campo dos negócios, pois a partir da animosidade com os dados da exportação que o Estado do Pará vivia no início do século XX, Moju era um dos municípios que somava dentro do setor de produção. Nesse sentido, ter mais mão-de-obra qualificada era crucial para o aumento na produção.

Com o passar dos tempos, é possível ver o quanto o município progrediu com o investimento no setor educacional, os sujeitos e as estruturas resultantes desse processo são expostos no atual quadro de profissionais e organização que constituem o Município de Moju.

No ensejo da construção histórica do sistema de ensino de Moju, o Grupo Escolar Lauro Sodré é a referência que se tem por ser a primeira instituição de ensino, construída e mantida pelo Estado no Município.

Embora a política educacional através da regulamentação do ensino tenha mudado o endereço da instituição e em sequência a nomenclatura de Grupo para Escola, mesmo assim, a instituição de ensino Lauro Sodré continua contribuindo com o processo formativo dos educandos que fazem parte de sua comunidade.

Recriar a história do Grupo Escolar Lauro Sodré mostrou que ainda há muito a ser pesquisado sobre o passado e o presente das instituições de ensino no Brasil, no Estado do Pará e nos municípios da região Guajarina. Mostrou também a importância da preservação documental dos livros, atas, boletins, iconografias, entrevistas etc., tudo o que diz respeito à história das instituições de ensino, para possibilitar o enriquecimento educacional e cultural da sociedade.

\section{Referencias}

AZEVEDO, Crislane. Profissão docente: a formação das professoras dos grupos escolares de Sergipe no início do Século XX (19111930). Cultura Escolar Migrações e Cidadania Actas do VII Congresso LUSOBRASILEIRO de História da Educação 2023 Junho 2008, Porto: Faculdade de Psicologia e Ciências da Educação (Universidade do Porto). Disponível em: http://web.letras.up.pt/7clbheporto/trabalhos_finais/eixo5/IE143.pdf. Acessado em: 07/10/2009

BITTAR, Marisa. JUNIOR, Amarilio Ferreira. DITADURA MILITAR E A PROLETARIZAÇÃO DOS PROFESSORES. Revista Educação e Sociedade. Campinas: vol. 27, n. 97, p. 1159-1179, 2006. Disponível em: http://www.scielo.br/pdf/es/v27n97/a05v2797.pdf. Acesso em: 19/03/2010

BRASIL, Lei de Diretrizes e Bases da Educação Nacional: Lei 9.394/96. Rio de Janeiro: DP\&A, 2003

BRASIL, República Federativa do Brasil, LEI No 4.024, DE 20 DE DEZEMBRO DE 1961Disponível em: http://www.jusbrasil.com.br/legislacao/108164/lei-de-diretrizes-e-base-de1961-lei-4024-61. Acessado em: 09/05/2009

BRASIL, República Federativa do Brasil, LEI NO 5.692, DE 11 DE AGOSTO DE 1971 Disponível em: http://www.jusbrasil.com.br/legislacao/128525/lei-de-diretrizes-e-base-de1971-lei-5692-71, Acesso em: 15/04/2009

Revista HISTEDBR On-line, Campinas, $n^{o}$ 62, p.121-143, mai2015 - ISSN: 1676-2584140 
GONÇALVES, N. G. . A escola e o arquivo escolar: discutindo possibilidades de interlocução entre atividades de ensino, pesquisa e extensão. In: IV Congresso Brasileiro de História da Educação - A Educação e seus Sujeitos na História, 2006, Goiânia. Anais do IV Congresso Brasileiro de História da Educação. Goiânia : UCG, 2006. v. I. p. 1-10.

LE GOFF, J. História e Memória. Campinas: UNICAMP, 1996

LIMA, José Valber Sales. Moju - Rio das Cobras. Belém: S.E., 2000

Livro Ata das Reuniões Administrativas e Pedagógicas da Escola Lauro Sodré. Moju: 1977. S.Ed, S.D

Livro de Tombo da Paróquia do Divino Espírito Santo, (S. Ed. S.D) 1952

MARIN, Rosa Elisabeth Acevedo. Estruturas camponesas no Pará colonial: ocupação da terra e dinâmica demográfica em Freguesia da Comarca de Belém no final do século XVIII. Comunicação apresentada no XXI Simpósio Nacional de História. Niterói, Associação Nacional de História - ANPUH \& Universidade Federal Fluminense, 2001. Disponível em:http://historia_demografica.tripod.com/nec/bhd31.pdf. Acesso em: 15/03/2010

MEDEIROS, Ruy. Arquivos escolares: breve introdução a seu conhecimento. In: SIMPÓSIO DO MUSEU PEDAGÓGICO, 3, 2003, Bahia. Disponível em: $<$ http://www.histedbr.fae.unicamp.br >.

MOJU, Poder Legislativo. Câmara de Vereadores. Ata de Reuniões Parlamentar 1975. S.Ed. S.D

MOJU, Poder Legislativo. Câmara de Vereadores. Ata de Reuniões Parlamentar 1977. S.Ed. S.D

MOREIRA NETO, C.A. Índios da Amazônia, de maioria a minoria (1750-1850). Petrópolis: Ed. Vozes. 1988

NOZOE, N. H. Sesmaria e apossamento de terras no Brasil Colônia. Economia, Brasília, v. 7, p. 587-605, $2006 . \quad$ Disponível em: http://www.usp.br/feaecon/incs/download.php?i=75\&file=../media/livros/file_75.pdf. Acesso em: 19/03/09.

PARÁ, Arquivo Público do Estado do Pará. Coleção de leis da Província do Grão Pará de1835 a 1845. Tomo VI - 1843 - Parte I

PARÁ, Presidente da Província - 1869 - 1870. João Alfredo Correia de Oliveira. Relatorio apresentado á Assembléa Legislativa Provincial na primeira sessão da 17. Pará, Typ. do Diario do Gram-Pará, 1870.

PARÁ. Governador, 1901 - 1908 (Augusto Montenegro). Mensagem ao Congresso Legislativo do Pará. Belém: Imprensa Oficial, 1907.

PARÁ. Governador, 1901 - 1908 (Augusto Montenegro). Mensagem ao Congresso Legislativo do Pará. Belém: Imprensa Oficial, 1906.

PARÁ. Governador, 1909 - 1912 (João Antônio Luiz Coelho). Mensagem ao Congresso Legislativo do Pará. Belém: Imprensa Oficial do Estado do Pará, 1910.

PARÁ. Governador, 1912 - 1916 (Eneas Martins). Mensagem ao Congresso Legislativo do Pará. Belém: Imprensa Oficial do Estado do Pará. 1916.

PARÁ. Governador, 1966 - 1971 (Alacid da Silva Nunes). Mensagem apresentada à Assembleia Legislativa do Estado do Pará. Belém: Imprensa Oficial do Estado do Pará. 1968 
ROSÁRIO, Maria José Aviz do. O PCB e a organização do ensino público primário de Belém do Pará (1945 a 1964). 2006. 214 f. Tese (Doutorado) - Programa de Pós-Graduação em Educação, Universidade Federal de São Carlos, São Carlos, 2006.

SACRAMENTO, Elias Diniz. A luta pela terra numa parte da Amazônia: O trágico 07 de setembro de 1984 em Moju e seus desdobramentos. Belém: Açaí, 2009

SAMPAIO, M. R. M. Uma visita à educação no Pará cem anos atrás. Revista de Cultura do Pará, Belém, v. 15, 2004. Disponível em: http://www.reginamaneschy.pro.br/pdf/visita.pdf. Acesso em: 15/09/2010

SOUZA, Orlando Nobre Bezerra. A MUNICIPALIZAÇÃO DA EDUCAÇÃO NO ESTADO DO PARÁ E OS MARCOS FUNDAMENTAIS DE RESISTÊNCIA. Anais da 57 $7^{\text {a }}$ Reunião Anual da SBPC - Fortaleza, CE - Julho/2005. Disponível em: http://www.sbpcnet.org.br/livro/57ra/programas/SENIOR/RESUMOS/resumo_1472.html. Acesso em: 24/02/2010

VIDAL, Diana Gonçalves (org.) Grupos Escoalres: cultura escolar primária e escolarização da infância no Brasil (1893-1971). Campinas/SP: Mercado de Letras, 2006

\footnotetext{
${ }^{1}$ Doutorando do Programa de Pós-Graduação em Educação PPGED/UFPA; Mestre em Educação; Especialista em História e Filosofia da Educação; Pesquisador do Núcleo de Estudos e Pesquisa em Currículo-NEPEC. email: renatopc@bol.com.br

${ }^{2}$ Doutor em Educação: Currículo pela Pontifícia Universidade Católica de São Paulo; Docente pesquisador no Programa de Pós-Graduação em Educação e na Faculdade de Educação do Instituto de Ciências da Educação da Universidade Federal do Pará; Líder do Núcleo de Estudos e Pesquisa em Currículo - NEPEC. e-mail: paulosac@ufpa.br

${ }^{3}$ Mercantilismo é o nome dado a um conjunto de práticas econômicas desenvolvido na Europa na Idade Moderna, entre o século XV e os finais do século XVIII

${ }^{4}$ No período imperial o nome do Estado do Pará era Província do Grão-Pará compreendendo a região dos Estados do Amazonas, Roraima, Pará, Amapá, Maranhão e Piauí

${ }^{5}$ Capitão Mor fundador da vila de Moju

${ }^{6}$ Segundo Barata (2000) Inácio Vaz Chaves foi proprietário de uma sesmaria no rio Moju, passada por Carta de 05.09.1739

${ }^{7}$ Segundo Barata e Bueno (2000) Antônio Manuel Correia de Miranda, primeiro e único barão de Cairari (Igarapé-Miri, 18 de setembro de 1831 - Belém, 20 de agosto de 1903) foi um militar e político brasileiro. O Barão de Cairari (grafado originalmente "Barão de Cairary"), nasceu na rica e opulenta propriedade Santo Antônio, em 18 de setembro de 1831 e era filho do tenente-coronel das antigas milícias Manuel João Correia de Miranda e de Alexandrina Antonia Sousa Miranda. Foi casado com Leopoldina Campos e tiveram quatro filhos, dos quais apenas sobreviveram dois: Antônio Miranda Filho e Eufrosina Miranda.Foi comerciante e proprietário de terras. Foi também deputado provincial, vereador da Câmara Municipal de Moju; Juiz de Paz; Guarda Nacional qualificado em 10 de julho de 1851, promovido a tenente da Oitava Companhia do Décimo primeiro Batalhão de Infantaria de "Igarapé-Miry" (grafado atualmente como Igarapé-Miri) em 25 de julho de 1854; a Capitão Comandante da segunda Companhia avulsa em 24 de maio de 1858; a Major comandante de uma seção de batalhão em 1 de maio de 1863; a tenente coronel comandante do 21 Batalhão de Infantaria, por decreto de 20 de outubro de 1869; a Coronel comandante superior por decreto de 31 de dezembro de 1870, posto este em que foi reformado por decreto de 22 de junho de 1872

${ }^{8} \mathrm{O}$ Distrito de Cairary referido nas mensagens dos governos e em fontes históricas ao que tudo indica era sediado na localidade da Vila de N. Sr ${ }^{\mathrm{a}}$ da Soledade no alto rio Moju. Esta vila até o início do século XX era muito movimentada chegando nela a ser erguida uma paróquia no ano de 1839, contudo devido a uma epidemia de varíola ocorrida nos anos 30, causa da morte de muitos moradores, a localidade deixou de ter estimado valor para a região

${ }_{9}^{9}$ Pelos dados registrados no site Luz no Horizonte - http://www.masonic.com.br/rito/sodre.htm, Lauro Nina Sodré e Silva, nasceu em Belém a 17/10/1858, foi militar, político e líder republicano. Iniciou seus estudos no Liceu Paraense, seguindo, depois, a carreira de engenheiro militar, no curso da Escola da Praia Vermelha, no
} 
Rio de Janeiro, onde ingressou em janeiro de 1877 tendo como mestre o republicano e maçom Benjamin Constant, quem o levou (como a tantos outros jovens oficiais e cadetes) a abraçar a causa da República e a doutrina positivista de Comte. Durante a Proclamação da República Lauro Sodré foi secretário de Benjamin Constante no Ministério da Guerra e lente catedrático da Escola Superior de Guerra. Foi eleito duas vezes para o cargo de Governador do Estado do Pará, a primeira vez nos anos 1891 a 1897 e a segunda vez entre 1917 a 1921. Outro cargo político exercido por Lauro Sodré foi o de Senador da República, sendo eleito por três vezes pelo Estado do Pará (1897,1912 e 1922) e uma quarta vez pelo Distrito Federal (1902). Lauro Sodré faleceu no Rio de Janeiro em 1944. Por seu currículo político e profissional, e pelo país estar sob o governo do regime militar, pode ser este um dos fortes motivos para que o nome de Lauro Sodré tenha sido escolhido para marcar a presença do poder do Estado em Moju, indicando a característica que o sistema de ensino deveria ter, pautado em uma ordem disciplinar e positivista

${ }^{10}$ Segundo relado no Livro de Tombo da Paróquia do Divino Espírito Santo (1952. p.5) O prédio da Prefeitura Municipal, Palácio Municipal Dr. João Coelho, foi inaugurado no dia 31 de janeiro de 1954 pelo prefeito Oscar Correa de Miranda

${ }^{11}$ Muitos atribuem a denominação Pa 252 a rodovia estadual que passa por Moju, no entanto essa é a rodovia que liga a Pa 150 com o Município de Acará, como indica o mapa da SEIR - GEOPARÁ (JUN/2004)

${ }^{12}$ Segundo o testemunho de ex-alunos e moradores antigos o Casulo Municipal funcionava na antiga Capela de São Sebastião, atualmente sede do Sindicato dos Trabalhadores Rurais de Moju

${ }^{13}$ Em algumas instituições este arquivo e intitulado de "Arquivo Morto", por se tratar de dados e informações do passado da instituição e que não têm aparente importância para as atividades da Escola, ou como denominam Camargo e Bellotto (1996, p.8) “ [...] depósito onde se acumulam os documentos já não necessários à administração, mas que ainda guardam valor legal."

${ }^{14}$ Em reconhecimento à dedicação e ao trabalho na educação do município, o Governo do Estado no ano de 1991 homenageia a Professora Ernestina Pereira Maia dedicando a sua memória o prédio da Escola de $2^{\circ}$ grau do Município, como consta na Portaria $n^{\circ}$ 003/91-GS Art. $1^{\circ}$ - Fica criada a Escola Estadual de $1^{\circ}$ e $2^{\circ}$ graus Professora Ernestina Pereira Maia, localizada na sede do Município de Moju, à rua da Saudade s/n Bairro Alto; Art. $2^{\circ}$ - A denominação, a que se refere o artigo anterior, representa uma homenagem da comunidade local à memória da ilustre mestra, que tantos e tão relevantes serviços prestou à comunidade daquele município ${ }^{15}$ Até o ano de 2001 a Escola Lauro Sodré era Estadual, mas com o processo da municipalização desenvolvido pelo Governo Federal Estadual a Escola passou a ser municipal. As turmas de ensino médio que atualmente funcionam em fazem parte do anexo da Escola Estadual de Ensino Médio Ernestina Pereira Maia.

${ }^{16}$ A Escola Antônio de Oliveira Gordo foi inaugurada no ano de 1982 para atender a crescente demanda do ensino do primeiro grau. Atualmente ela é municipalizada funcionando em regime de convênio com o Estado para o funcionamento do ensino médio como anexo da Escola Ernestina Pereira Maia

Recebido: abr/15 Aprovado: jun/15 